\title{
Penggunaan Skor Apfel sebagai Prediktor Kejadian Mual dan Muntah Pascaoperasi di RSUP Dr. Hasan Sadikin Bandung
}

\author{
Rachmad Try Hendro, ${ }^{1}$ Erwin Pradian, ${ }^{2}$ Indriasari ${ }^{2}$ \\ ${ }^{1}$ Bagian Anestesi Rumah Sakit Umum Daerah Lubuk Basung Kabupaten Agam, \\ ${ }^{2}$ Departemen Anestesiologi dan Terapi Intensif Fakultas Kedokteran Universitas Padjadjaran/ \\ RSUP Dr. Hasan Sadikin Bandung
}

\begin{abstract}
Abstrak
Post operative nausea and vomiting (PONV) merupakan kejadian mual dan atau muntah setelah tindakan operasi menggunakan anestesi pada 24 jam pertama pascaoperasi. Kejadian PONV dilaporkan memiliki perbedaan pada berbagai bangsa dan etnis. Skor Apfel merupakan salah satu prediktor PONV yang objektif dan paling sederhana. Sebelum menggunakannya sebagai prosedur rutin di RSHS, dilakukan penelitian ini yang bertujuan menilai apakah skor Apfel dapat digunakan sebagai prediktor PONV pada pasien yang menjalani operasi dengan anestesi umum di RSHS. Dilakukan suatu studi diagnostik secara potong lintang pada 100 pasien yang menjalani operasi elektif dengan anestesi umum di RSHS pada bulan SeptemberOktober 2017. Subjek penelitian dikelompokkan dalam 5 kelompok skor Apfel, yaitu perempuan, tidak merokok, menggunakan opioid pascaoperasi, dan memiliki riwayat PONV sebelumnya. Hasil penelitian ini menunjukkan terdapat 42\% angka kejadian PONV, terdiri atas skor Apfel 0 (8,3\%), skor 1 (19,04\%), skor 2 $(36,6 \%)$, skor $3(63,63 \%)$, dan skor $4(80 \%)$ yang sesuai dengan nilai prediktif skor Apfel. Angka kejadian PONV pada skor Apfel risiko tinggi $(\geq 3) 61,9 \%$, bermakna secara signifikan dapat membedakan kejadian PONV dengan nilai sensitivitas 61,9\%, spesifisitas 81,0\%, dan nilai AUC 0,777. Hasil ini menunjukkan bahwa skor Apfel memiliki validitas yang baik untuk membedakan antara pasien yang akan mengalami PONV dan yang tidak. Simpulan penelitian ini, skor Apfel dapat dipakai untuk memprediksi kejadian PONV di RSHS.
\end{abstract}

Kata kunci: Post operative nausea and vomiting, prediktor, skor Apfel, validitas

\section{Use of Apfel Score as a Predictor for Post-Post-operative Nausea and Vomiting in Dr. Hasan Sadikin General Hospital}

\begin{abstract}
Post-operative nausea and vomiting (PONV) is defined as any nausea, retching, or vomiting that occurs during the first 24 hour after surgery. Previous studies have reported that nationality and ethnicity influence the incidence of PONV. Apfel score is one of the objective and best simplified predicting PONV scoring systems available. Until recently, no predicting PONV score is used in Dr. Hasan Sadikin General Hospital (RSHS). Before implementing any scoring system as a protocol in this hospital, validation of the clinical risk assessment score in the hospital setu is needed. This was a cross-sectional diagnostic study on 100 patients underwentpost- various elective surgeries under general anesthesia. Subjects were divided into five groups, based on the Apfel risk scoring system. Factors observed consisted of four factors: female gender, nonsmoking status, post-operative use of opioids, and history of PONV or motion sickness. The results were analyzed for total incidence of PONV in each Apfel score group. Of 100 patients assessed, a total of 42\% experienced PONV. Patients in Apfel score 0, 1, 2, 3, and 4 presented a PONV incidence score of $8.3 \%, 19.04 \%, 36.6 \%, 63.63 \%$, and $80 \%$, respectively. This incidence corresponds to the previous predicted values Apfel score. The incidence of PONV in patients under high risk Apfel score $(\geq 3)$ was $61.9 \%$, showing a significant correlation with PONV. The sensitivity was $61.9 \%$, the specificity was $81.0 \%$, and the AUC value was 0.777 . This confirms that Apfel score has good validity to predict the incidence of PONV. In conclusion, Apfel scoring system is useful for identifying patients with PONV in RSHS.
\end{abstract}

Key words: Apfel score, post-post-operative nausea and vomiting, predictor, validity

Korespondensi: Rachmad Try Hendro, dr., SpAn, Bagian Anestesi Rumah Sakit Umum Daerah Lubuk Basung Kabupaten Agam, Jl. dr. M. Hatta-Padang Baru, Lubuk Basung, Kabupaten Agam-Sumatera Barat, Email rachmadbob2@gmail.com 


\section{Pendahuluan}

Post operative nausea and vomiting (PONV) atau mual dan muntah pascaoperasi adalah komplikasi yang paling sering terjadi setelah tindakan operasi dengan anestesi pada 24 jam pertama pascaoperasi. ${ }^{1}$ Pasien yang menjalani operasi dilaporkan $25-30 \%$ mengalami PONV. ${ }^{2}$

Kejadian pada PONV dilaporkan memiliki perbedaan dalam berbagai etnis., ${ }^{3,4}$ Angka kejadian PONV di beberapa rumah sakit di Indonesia, pernah dilaporkan mencapai $27,08 \%{ }^{5}$ dan $31 \% .{ }^{6}$ Kejadian PONV di RSUP Dr. Hasan Sadikin Bandung sebagai pusat rujukan Provinsi Jawa Barat hingga kini belum pernah dilaporkan.

Post operative nausea and vomiting (PONV) hampir selalu hilang dengan sendirinya, tetapi dapat menyebabkan ketidaknyamanan dan ketidakpuasan pasien setelah operasi, ${ }^{7}$ bahkan dapat menimbulkan komplikasi yang serius. ${ }^{1}$ Selain itu, setiap kejadian muntah akan menunda keluarnya pasien dari ruang pemulihan selama kurang lebih 20 menit yang tentunya akan meningkatkan biaya perawatan. $^{2}$

Penentuan risiko tinggi kejadian PONV ditentukan dengan skor faktor risiko PONV. ${ }^{1,8}$ Beberapa sistem skor telah diperkenalkan untuk memprediksi PONV dalam 24 jam setelah operasi. ${ }^{9}$ Hingga saat ini belum ada sistem skor prediksi PONV yang dijadikan sebagai baku emas (gold standard) berdasar atas akurasinya. Skor paling sederhana adalah skor Apfel, terdiri atas 4 faktor risiko, yaitu jenis kelamin perempuan, tidak merokok, riwayat PONV atau morning sickness sebelumnya, dan penggunaan opioid pascaoperasi. ${ }^{2,8}$ Tiap-tiap faktor risiko tersebut meningkatkan kejadian PONV 20\%. ${ }^{8}$ Skor Apfel dilaporkan memiliki kemampuan diskriminasi yang lebih tinggi daripada skor lainnya dalam memprediksi kejadian PONV. ${ }^{2}$ Dalam American Society of Perianesthesia Nurse (ASPAN's) Guideline for Prevention and/or Management of PONV, skor Apfel digunakan dalam menilai golongan pasien berdasar atas risiko terhadap PONV. ${ }^{1}$

Hingga saat ini belum pernah dilakukan penilaian risiko PONV pasien yang menjalani operasi dengan anestesi umum di RSUP Dr. Hasan Sadikin Bandung. Berdasar atas hal tersebut, diperlukan uji validasi terhadap instrumen penilaian skor PONV yang objektif dan paling sederhana, yaitu skor Apfel pada populasi pasien di RSUP Dr. Hasan Sadikin sebagai prediktor kejadian PONV sebelum menggunakannya sebagai alat skrining rutin. Kejadian PONV yang dapat diprediksi dapat menjadi dasar pemberian antiemetik profilaksis. $^{8}$

Tujuan penelitian ini adalah mengetahui angka kejadian PONV pada pasien dengan anestesi umum di RSUP Dr. Hasan Sadikin Bandung dibanding dengan angka prediksi skor Apfel dan mengetahui validitas skor Apfel sebagai prediktor kejadian PONV pada pasien yang dilakukan anestesi umum di RSUP Dr. Hasan Sadikin.

\section{Subjek dan Metode}

Penelitian ini merupakan uji diagnostik secara cross sectional yang dilakukan di RSUP Dr. Hasan Sadikin Bandung pada bulan September hingga Oktober 2017. Subjek penelitian ini adalah 100 pasien yang menjalani operasi dengan anestesi umum di RSUP Dr. Hasan Sadikin Bandung (RSHS) yang memenuhi kriteria inklusi dan tidak termasuk kriteria eksklusi.

Kriteria inklusi meliputi usia 18-60 tahun, menjalani operasi elektif dengan anestesi umum, status fisik berdasar atas American Society of Anesthesiologist (ASA) kelas I dan II, memenuhi persiapan operasi sesuai lembar presedasi, dan durasi operasi 90 hingga 150 menit. Kriteria eksklusi meliputi operasi one day surgery, operasi laparoskopik, neurosurgeri, kardiotorasik, strabismus, obstetri, mastektomi, serta tonsilektomi. Kriteria pengeluaran pada penelitian ini adalah terjadi komplikasi berat pascaoperasi, yaitu infark miokardium akut, gagal jantung akut, edema paru akut, pneumotoraks, dan pasien yang memerlukan perawatan pascaoperasi di ruang intensif, pasien yang tidak diekstubasi setelah operasi, dan terdapat kejadian muntah sesaat sebelum anestesi. 
Perhitungan jumlah sampel pada penelitian ini mempergunakan pendapat Gay dan Diehl, minimal sampel yang diperlukan adalah 60 orang. Sampel dipilih dengan metode consecutive sampling terhadap seluruh pasien yang menjalani operasi elektif dengan anestesi umum yang memenuhi kriteria inklusi dan tidak termasuk kriteria eksklusi. Jumlah sampel pada penelitian ini adalah 100 orang.

Penelitian dilakukan setelah mendapat persetujuan dari Komite Etik Penelitian Kesehatan Fakultas Kedokteran Universitas Padjadjaran/Rumah Sakit Umum Pusat Dr. Hasan Sadikin Bandung. Penelitian dimulai dengan penilaian skor Apfel yang dilakukan sebelum induksi anestesi, sedangkan penilaian kejadian PONV dilakukan saat pertama kali sampai di ruang pemulihan, enam jam pascaoperasi dan 24 jam pascaoperasi di ruang perawatan.

Variabel yang dinilai adalah skor Apfel yang didapat dari hasil pengukuran empat faktor risiko pada setiap sampel, yaitu jenis kelamin perempuan, tidak merokok, riwayat PONV/ motion sickness sebelumnya, dan penggunaan opioid pascaoperasi. Setiap faktor risiko mendapat skor 1 jika ditemukan pada sampel sehingga skor terendah 0 dan tertinggi 4. Varibel kejadian PONV dinilai dengan menggunakan grade. Grade 1 adalah subjek penelitian yang mengalami mual, tetapi tidak muntah, sedangkan grade 2 adalah subjek penelitian yang mengalami mual dan muntah. Grade 1 dan 2 digolongkan mengalami PONV dan grade 0 adalah tidak mengalami PONV. Kejadian PONV didapat dari hasil wawancara kepada pasien atau perawat dalam 24 jam setelah operasi. Wawancara dilakukan oleh dokter anestesi.

Kejadian PONV pada tiap kelompok skor Apfel dihitung dan dianalisis dengan uji chisquare, penilaian nilai area under the curve (AUC), sensitivitas, serta spesifisitas. Data yang didapat diolah menggunakan program statistical product and servise solution (SPSS) versi 24.0 for windows.
Tabel 1 Karakteristik Subjek Penelitian

\begin{tabular}{lc}
\hline \multicolumn{1}{c}{ Variabel } & $\mathbf{n = 1 0 0}$ \\
\hline Usia (tahun) & \\
Mean \pm STD & $33,80 \pm 12,788$ \\
Median & 32,000 \\
Range (min.-maks.) & $18,00-60,00$
\end{tabular}

Jenis kelamin, $\mathrm{n}$

Perempuan 56

Laki-laki 44

Status merokok, $\mathrm{n} \quad 68$

Ya

Tidak

Penggunaan opioid pascaoperasi, $\mathrm{n}$

Ya

Tidak

Riwayat PONV/motion sickness, $\mathrm{n}$

Ya

Tidak

Jenis operasi, $\mathrm{n}$

Odontektomi 27

Nekrotomi deberidement 22

Biopsi eksisi 13

Biopsi insisi 2

Labiognatoplasti 2

FEES dan septoplasti 10

ORIF 7

Tiroidektomi 15

Uretrokopi 2

Lama operasi (jam), $\mathrm{n}$

Mean \pm STD 2,00 $\pm 0,313$

Median 2,000

Range (min.-maks.) $\quad 1,50-2,50$

Penambahan fentanil intraoperasi, $\mathrm{n}$

Ya 62

Tidak 38

Keterangan: data kategorik disajikan dengan jumlah/ frekuensi dan persentase, sedangkan data numerik disajikan dengan rerata, median, standar deviasi, dan range 
Tabel 2 Frekuensi Kejadian PONV

\begin{tabular}{lc}
\hline \multicolumn{1}{c}{ Variabel } & $\mathbf{n = 1 0 0}$ \\
\hline Skor Apfel, $\mathrm{n}$ & 2,000 \\
Median & $0,00-4,00$ \\
Range (min.-maks.) & 12 \\
0 & 21 \\
1 & 30 \\
2 & 22 \\
3 & 15 \\
4 & \\
Kejadian PONV, $\mathrm{n}$ & 42 \\
Ya (grade 1 dan 2) & 58 \\
Tidak (grade 0) & \\
Grade PONV, $\mathrm{n}$ & 58 \\
Grade 0 (tidak mual dan & \\
muntah) & 31 \\
Grade 1 (mual, tidak muntah) & 11 \\
Grade 2 (mual dan muntah) & \\
Waktu Kejadian PONV, $\mathrm{n}$ & 2 \\
Pascaoperasi & \\
6 jam pascaoperasi & \\
24 jam pascaoperasi & \\
\hline
\end{tabular}

Keterangan: data kategorik disajikan dengan jumlah/ frekuensi dan persentase

\section{Hasil}

Dari 100 pasien yang menjadi subjek penelitian ini, mempunyai rerata usia sebesar 33,80 tahun. Subjek penelitian didominasi pasien perempuan, tidak merokok, menggunakan opioid pascaoperasi, dan tidak memiliki riwayat $\mathrm{PONV} /$ motion sickness sebelumnya. Karakteristik lengkap subjek penelitian terlihat pada Tabel 1.

Dari 100 subjek penelitian, skor Apfel terbanyak didapatkan pada skor 2, yaitu 30 orang (30\%). Didapatkan $42 \%$ dari seluruh subjek penelitian mengalami kejadian PONV, yang terdiri atas 31\% PONV grade 1 dan $11 \%$ PONV grade 2. Kejadian PONV paling banyak terjadi pada 6 jam pascaoperasi (Tabel 2).

Pada hasil penelitian ini, kejadian PONV semakin meningkat seiring dengan
Tabel 3 Kejadian PONV berdasar atas Skor Apfel

\begin{tabular}{ccc}
\hline Skor Apfel & Jumlah & Kejadian PONV \\
\hline 0 & 12 & $1(8 \%)$ \\
1 & 21 & $4(19 \%)$ \\
2 & 30 & $11(37 \%)$ \\
3 & 22 & $14(63 \%)$ \\
4 & 15 & $12(80 \%)$ \\
\hline
\end{tabular}

Keterangan: data kategorik disajikan dengan jumlah/ frekuensi dan persentase

meningkatnya skor Apfel. Penambahan 1 skor Apfel menambah insidensi kejadian PONV sekitar 20\% (Tabel 3). Persentase kejadian PONV pada tiap kelompok skor Apfel pada penelitian ini serupa dengan prediksi skor Apfel, yang dilakukan Apfel pada tahun 1999 Semakin meningkat skor Apfel maka insidensi PONV juga semakin meningkat (Gambar 1).

Skor Apfel dapat membedakan kelompok pasien dengan risiko tinggi mengalami PONV dan dengan risiko rendah. Pada penelitian ini didapatkan cut-off skor Apfel adalah 3, menunjukkan nilai skor Apfel $\geq 3$ memiliki kejadian PONV yang lebih tinggi daripada skor Apfel $<3$, dengan perbedaan signifikan bermakna secara statistik. Skor Apfel $\geq 3$ memiliki nilai senstivitas $61,9 \%$ dan nilai spesifisitas 81,0\% (Tabel 4). Hal ini berarti $61,9 \%$ pasien dengan skor Apfel $\geq 3$ diprediksi mengalami PONV.

Nilai duga positif (NDP) sebesar 70,2\% menunjukkan NDP yang sedang secara statistik, sedangkan nilai duga negatif (NDN) sangat kuat pada uji diagnostik ini, yaitu sebesar 93,6\%. Untuk nilai akurasi sebesar 73,0\% menunjukkan tingkat nilai akurasi yang sedang secara statistik.

Dari hasil analisis perbandingan kedua kelompok penelitian ini, yaitu kelompok PONV dan tidak PONV, dapat disimpulkan kedua kelompok tersebut memiliki jumlah skor Apfel yang signifikan berbeda. Kelompok PONV memiliki skor Apfel $\geq 3$, sedangkan kelompok tidak PONV memiliki skor Apfel $<3$. Maka dapat disimpulkan secara statistik 
Tabel 4 Perbandingan Proporsi atau Hubungan antara Kategori Skor Apfel pada Kelompok Kejadian PONV dan Kelompok Tidak PONV

\begin{tabular}{|c|c|c|c|}
\hline \multirow[b]{2}{*}{ Skor APFEL } & \multicolumn{2}{|c|}{ Kejadian PONV } & \multirow[b]{2}{*}{ Nilai $p$} \\
\hline & $\begin{array}{c}\text { Ya } \\
n=42\end{array}$ & $\begin{array}{l}\text { Tidak } \\
\mathrm{n}=58\end{array}$ & \\
\hline$\geq 3$ & 26 & 11 & $0,000 * *$ \\
\hline$<3$ & 16 & 47 & \\
\hline
\end{tabular}

Keterangan: data kategorik nilai p dihitung berdasar atas uji chi-square dengan alternatif Uji Kolmogorov Smirnov dan Exact Fisher apabila syarat dari chi-square tidak terpenuhi. Nilai kemaknaan berdasar atas nilai p $<0,05$ Tanda* menunjukkan nilai $\mathrm{p}<0,05$ artinya signifkan atau bermakna secara statistik

bahwa terdapat hubungan skor Apfel $\geq 3$ dengan kejadian PONV.

Nilai diagnostik skor Apfel dihitung nilai area under the curve (AUC) melalui kurva receiver operating characteristic (ROC) (Gambar 2). Kurva ROC memperlihatkan bahwa skor Apfel mempunyai nilai diagnostik yang baik karena kurva menjauh dari garis $50 \%$ dan mendekati $100 \%$. Nilai AUC yang diperoleh dari metode ROC adalah sebesar $77,7 \%$ dengan nilai $\mathrm{p}$ sebesar 0,000 yang artinya signifikan. AUC 77,5\% memiliki arti bahwa skor Apfel dapat digunakan untuk memprediksi kejadian PONV secara tepat pada 78 pasien dari total 100 pasien (Gambar 2).

Berdasar atas interval kepercayaan, nilai skor Apfel berada pada level 68,3\% sampai
$86,7 \%$. Uji chi-square yang membandingkan AUC yang diperoleh indeks dengan nilai AUC 50\% menghasilkan nilai $\mathrm{p}<0,05$. Hal ini menunjukkan bahwa skor Apfel bermakna secara statistik dalam memprediksi kejadian PONV.

\section{Pembahasan}

Pada penelitian ini didapatkan karakteristik subjek penelitian jenis kelamin terbanyak adalah perempuan (56\%). Perempuan memiliki risiko 2 sampai 4 kali lebih banyak mengalami PONV daripada laki-laki karena pengaruh hormon gonadotropin, walaupun mekanismenya belum dapat dijelaskan secara rinci. Faktor ini merupakan faktor prediksi

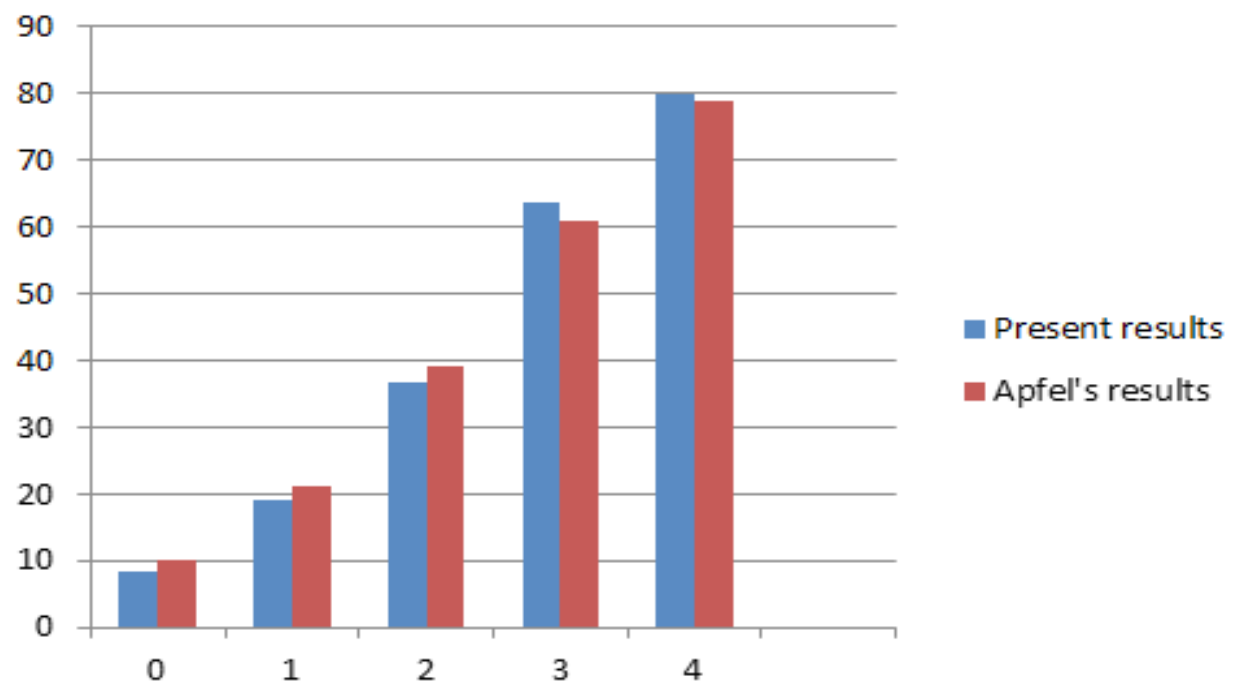

Gambar 1 Persentase Kejadian PONV pada Setiap Kelompok Skor Apfel Dibanding dengan Penelitian Apfel 


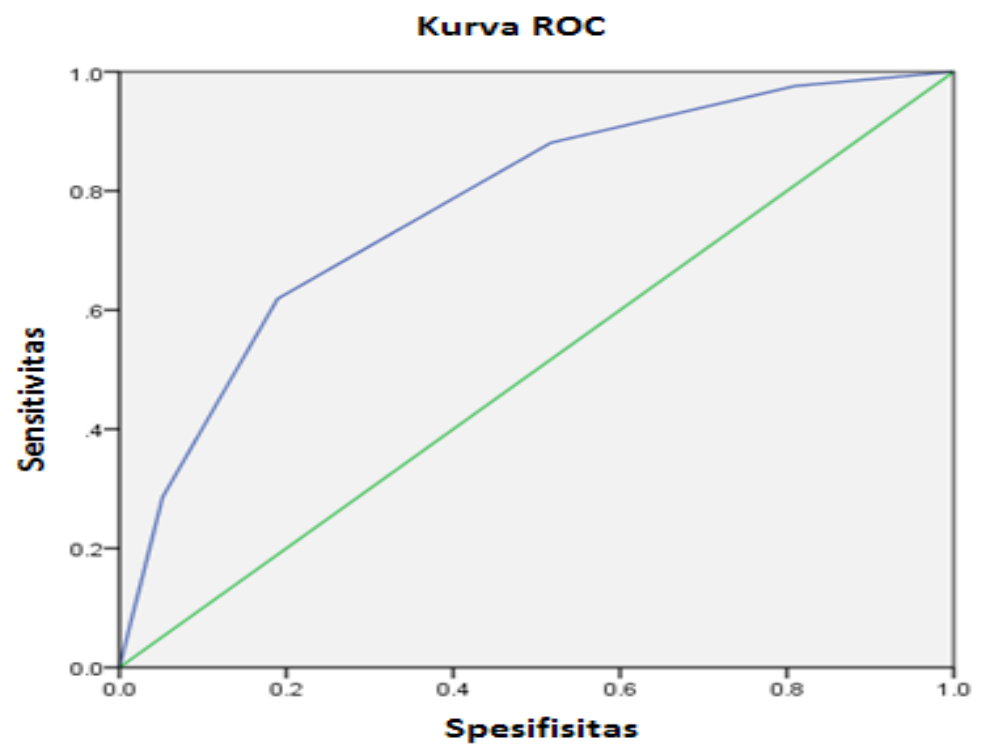

Gambar 2 Kurva Receiver Operating Characteristic Skor Apfel

terkuat terjadinya PONV dari 22 penelitian yang dilakukan systematic review. ${ }^{2}$

Subjek penelitian dengan status merokok lebih banyak daripada tidak merokok. Terdapat efek proteksi rokok terhadap kejadian PONV karena terdapat induksi enzim CYP450 oleh aromatik hidrokarbon polisiklik yang terdapat dalam tar rokok. Hal tersebut menyebabkan peningkatan metabolisme obat-obat anestesi. ${ }^{10}$

Subjek penelitian yang menggunakan opioid pascaoperasi lebih banyak daripada yang tidak. Opioid akan menstimulasi pusat muntah di otak, meningkatkan motilitas usus, dan meningkatkan sensitivitas vestibular sehingga memicu muntah. Dilaporkan terjadi peningkatan risiko PONV dua kali lipat pada penggunaan opioid. ${ }^{11}$ Penggunaan opioid pada pascaoperasi menjadi salah satu faktor risiko tinggi terjadinya PONV. ${ }^{7}$

Pasien yang sebelumnya mengalami PONV memiliki potensi yang lebih tinggi mengalami PONV kembali daripada yang tidak pernah mengalami PONV. ${ }^{2}$ Faktor ini juga termasuk faktor risiko tinggi terjadinya PONV. ${ }^{7}$ Pelepasan katekolamin pada pasien dengan riwayat $\mathrm{PONV}$ sebelumnya akan merangsang reseptor alpha di pusat muntah yang akan menyebabkan mual dan muntah. Namun, pada penelitian ini, subjek penelitian yang tidak memiliki riwayat PONV/motion sickness sebelumnya lebih banyak daripada yang memiliki.

Walaupun lama operasi dan usia pasien tidak menjadi kriteria penentuan skor prediksi PONV berdasar atas skor Apfel, pada penelitian ini didapatkan rerata subjek peneltian berusia 33,8 tahun dengan nilai tengah 32 tahun. Subjek termuda 18 tahun dan tertua 60 tahun. Pengaruh faktor usia dalam PONV digolongkan dalam moderate risk level karena hasil penelitian menunjukkan hasil yang berbeda-beda. ${ }^{7}$

Durasi operasi pada penelitian ini memiliki rerata 2 jam dengan nilai tengah 2 jam, dan tercepat 1,5 jam serta durasi terlama adalah 2,5 jam. Pengaruh durasi operasi ini berbedabeda dalam memengaruhi kejadian PONV dan digolongkan menjadi moderate risk factor PONV. 7 Dilaporkan kejadian PONV 2,8\% pada paparan anestesi selama $\leq 30$ menit dan meningkat menjadi $13-17 \%$ pada durasi operasi selama $90-150$ menit. $^{1}$

Angka kejadian PONV di dunia mencapai 25-30\%. Kejadian PONV dilaporkan memiliki perbedaan pada berbagai etnis. ${ }^{3,4}$ Pada penelitian ini kejadian PONV pada pasien 
operasi elektif dengan anestesi umum di RSUP Dr. Hasan Sadikin selama periode penelitian, yaitu September-Oktober 2017 lebih besar daripada angka insidensi umum tersebut, yaitu didapatkan 42\% dari 100 subjek penelitian. Angka kejadian yang sama di India, terdapat kejadian PONV sebesar $42 \%$ dari 150 pasien ASA I dan II yang menjalani operasi elektif dengan anestesi umum. ${ }^{8}$

Angka kejadian PONV di populasi bangsa di Eropa menunjukkan hasil yang tidak jauh berbeda, yaitu 44\% dan 38\% di Jerman, 48\% di Belanda, dan 56\% di Finlandia. ${ }^{2}$ Angka yang lebih rendah dilaporkan pada suku bangsa tertentu seperti pada bangsa Afrika, kejadian PONV 27\%. ${ }^{4}$ Angka 33\% dilaporkan dalam suatu penelitian di Singapura yang melibatkan subjek penelitian dari berbagai etnis Asia, yaitu Melayu, Cina, dan India. ${ }^{3}$ Di Indonesia, pernah dilaporkan angka kejadian PONV di dua rumah sakit yang berbeda, yaitu di RSCM Jakarta, tahun 2013 didapatkan angka kejadian PONV $31 \%{ }^{6}$ dan di RSUD Ulin Banjarmasin tahun 2014 sebanyak $27 \%{ }^{5}$

Perbedaan angka kejadian PONV di setiap populasi diduga berhubungan dengan faktor etnis.5,6 Perbedaan ini berkaitan dengn perbedaan ekspresi dan aktivitas sitokrom $P$ (CYP) 450 yang merupakan isoenzim yang memengaruhi metabolisme berbagai obatobat anestesi. Metabolisme obat anestesi yang lebih lama akan meningkatkan kejadian PONV. ${ }^{5}$

Pengelompokan skor prediksi kejadian PONV pada penelitian ini menggunakan skor Apfel. Dari 100 subjek penelitian, kelompok skor Apfel 2 merupakan kelompok yang terbanyak, yaitu $30 \%$, sedangkan yang paling sedikit adalah kelompok skor Apfel 0, yaitu $12 \%$. Tiap-tiap kejadian PONV pada tiap kelompok skor memiliki kecenderungan yang sama dengan berbagai penelitian yang menggunakan skor Apfel, yaitu setiap faktor risiko memiliki kecenderungan penambahan $20 \%$ kemungkinan mengalami PONV. ${ }^{2,8}$ Pada penelitian ini, skor Apfel 1 (satu faktor risiko yang terindentifikasi) memiliki kejadian PONV $19,04 \%$, kemudian tiap penambahan satu faktor risiko kejadian PONV meningkat sekitar
20\%. Hal ini terlihat kejadian PONV pada penelitian ini, yatu skor Apfel 2 (36,6\%), skor Apfel 3 (63,63\%), dan skor Apfel 4 (80\%).

Pada penelitian ini didapatkan skor Apfel $\geq 3$ terbukti bermakna menyebabkan kejadian PONV bila dibanding dengan skor Apfel $<3$. Hal ini sesuai dengan hasil peneliitan yang menggolongkan skor Apfel 3 dan 4 menjadi kelompok risiko tinggi mengalami PONV. ${ }^{9}$ Melihat hasil penelitian ini yang sesuai dengan penelitian sebelumnya maka skor Apfel 3 dan 4 dapat dijadikan sebagai batasan skor untuk pemberian terapi profilaksis antiemetik dan landasan pengamatan lebih ketat pada pasien dengan skor Apfel 3 dan 4 agar kejadian PONV dapat ditangani lebih awal.

Hasil perhitungan nilai AUC pada penelitian ini terhadap skor Apfel menunjukkan angka $77,7 \%(0,777)$ yang signifikan dapat membedakan antara kejadian PONV dan yang tidak. Jika dibandingkan dengan penelitian sebelumnya yang menggunakan skor Apfel, nilai AUC pada penelitian ini relatif lebih tinggi. Skor Apfel pernah dilaporkan memiliki nilai AUC 0,63-0,73 yang dilakukan pada beberapa populasi. ${ }^{2}$ Penelitian lain yang membandingkan berbagai populasi lain menunjukkan angka 0,65 , yaitu pada populasi pasien yang menjalani operasi ginekologi. Nilai yang lebih tinggi ditunjukkan pada populasi lain dengan nilai AUC mencapai 0,66. Dibanding dengan berbagai skor prediktor PONV lainnya, dengan nilai AUC skor Apfel lebih unggul. ${ }^{12}$ Dari perbandingan penggunaan skor Apfel sebelumnya, nilai AUC yang didapat dalam penelitian ini tergolong tinggi, menggambarkan 78 pasien diprediksi secara tepat oleh skor ini.

Hasil prediksi skor Apfel pada penelitian ini menunjukkan hasil yang lebih unggul daripada skor lainnya. Skor Koivuranta memiliki nilai AUC 0,65; sedangkan skor Pallazo memiliki nilai AUC 0,63; dan skor Evans memiliki nilai AUC $0,51 .{ }^{12} \mathrm{Hal}$ ini menunjukkan skor Apfel lebih unggul dalam memprediksi kejadian PONV, walaupun faktor risiko yang diidentifikasi skor Apfel lebih sedikit daripada skor lainnya. Dapat disimpulkan skor Apfel merupakan skor yang paling baik digunakan 
karena kemampuan prediksi yang lebih unggul daripada skor lain, serta merupakan skor yang paling sederhana karena hanya menghitung paling sedikit faktor risiko, yaitu empat faktor risiko.

Cut-off point skor Apfel yang didapatkan dalam penelitian ini adalah 3 dengan nilai sensitivitas $61,9 \%$ dan spesifisitas $81,0 \%$. Nilai spesifisitas tersebut lebih unggul daripada hasil yang dilaporkan peneliti sebelumnya yang melaporkan nilai AUC pada salah satu populasi sebesar 0,72 dengan nilai spesifisitas 58\%. dan sensitivitas $71 \%{ }^{13}$ Namun, nilai sensitivitas skor Apfel pada penelitian ini relatif lebih rendah, artinya jika ditemukan skor Apfel yang rendah $<3$, tetap diperlukan pengawasan akan kemungkinan terjadi PONV. Jika ditemukan skor Apfel 3 dan 4 perlu segera melakukan tata laksana pencegahan kejadian PONV.

Keterbatasan penelitian ini adalah jenis operasi terbatas pada operasi yang tidak memiliki risiko tinggi PONV sehingga hasil penelitian ini belum terbukti baik jika digunakan pada jenis operasi yang tergolong berisiko tinggi PONV seperti laporokopi, ginekologi, mastektomi, strabismus, dan timpanoplasti. ${ }^{12,13}$

\section{Simpulan}

Simpulan penelitian ini adalah angka kejadian PONV pada pasien dengan anestesi umum di RSUP Dr. Hasan Sadikin Bandung sesuai dengan angka prediksi skor Apfel. Skor Apfel memiliki validitas yang baik sebagai prediktor kejadian PONV yang ditunjukkan dengan nilai AUC sebesar 0,777. Skor Apfel dapat dijadikan pemeriksaan rutin untuk memprediksi risiko tinggi kejadian PONV sebelum pasien menjalani operasi dengan anestesi umum di seluruh RS di Indonesia pada umumnya dan di RSHS pada khususnya.

\section{Daftar Pustaka}

1. Pierre S. Naussea and vomitting after surgery. Contuining education in anaesthesia, critical care \& pain advance access. Br J Anaesth. 2012;13(4):28-32.

2. Apfel CC, Heidrich M, Jukar-rao S, Jalota L, Hornuss C, Whelan RP, dkk. Evidencebased analysis of risk factors for postoperative nausea and vomiting. $\mathrm{Br} \mathrm{J}$ Anaesth. 2012;12(3):1-12.

3. Leong XYU, Kwa XWC, Elizabeth SH, Koh LKD. Singapore General Hospital experience on ethnocity and the incidence of postoperative nausea and vomiting after elective orthopaedic surgery. J Anaesth. 2015;8(3):1-7.

4. Alli A, Omar S, Tsang T, Naik BI. The effect of ethnicity on the incidence of postoperative nausea and vomiting in moderate to high risk patients undergoing general anesthesia in South Africa: a controlled observational study. MEJ Anaesth. 2017;24(2):119-29.

5. Sholihah A, Marwan KS, Husairi A. Gambaran angka kejadian post operative nausea and vomiting (PONV) di RSUD Ulin Banjarmasin Mei-Juni 2014. Berkala Kedokteran. 2015;11(1):119-29.

6. Wijaya AA, Fithrah BA, Marsaban A, Hidayat J. Efektivitas pemberian cairan praoperatif ringer laktat $2 \mathrm{~mL} / \mathrm{kgBB} / \mathrm{jam}$ puasa untuk mencegah mual muntah pascaoperasi. JAP. 2014:2(3):200-7.

7. Collins AS. Postoperative nausea and vomiting in adults:implications for critical care. Crit Care Nurs. 2011;31(6):36-45.

8. Sherif L, Hedge R, Mariswani M, Ollapally A. Validation of the Apfel scoring system for identify high-risk patients for PONV. Karnataka Anaesth J. 2015;1:115-7.

9. Sadqa A, Khan BA, Raza G. The assessment of risk factors for postoperative nausea and vomiting. J Coll Physic Surg Pakistan. 2008;18(3):137-41.

10. Farhat K, Waheed A, Pasha AK, Iqbal J, Mansoor Q. Effect of smoking on nausea, vomiting, and pain in the postoperative periode. J Postgrad Med Inst. 2014;28(3):277-81.

11. Hambridge K. Assesing the risk of postoperative nausea and vomiting. Nurs Stand. 2012;27(18):35-43.

12. Wu YH, Sun HS, Wang ST, Tseng 
CC. Applicability of risk scores for postoperative nausea and vomiting in a Taiwanese population undergoing general anaesthesia. Anaesth Intens Care. 2015;43(4):473-8.

13. Kim SH, Shin YS, Oh YJ, Lee JR, Chung SC, Choi YS. Risk assessment of postoperative nausea and vomiting in the intravenous patient-controlled analgesia environment: predictive value of the Apfel's simplified risk score for identification high risk patients. Yonsei Med J. 2013;54(5):127381. 